vacuum cast palladium without the use of deoxidizer.

\section{Summary}

The creep rates of pure platinum, 90 pct $\mathrm{Pt}, 10$ pct $\mathrm{Rh}$ and pure palladium at $1382^{\circ} \mathrm{F}\left(750^{\circ} \mathrm{C}\right)$ have been determined using bars 0.290 in. in diam and stresses of 150 to $550 \mathrm{psi}$ in tests lasting up to 3000 $\mathrm{hr}$. The creep rate curves of platinum were normal for stresses of 250 and $400 \mathrm{psi}$. The creep rate of 90 pct $\mathrm{Pt}, 10$ pct $\mathrm{Rh}$, provided it was given a brief high temperature anneal $\left(1 \mathrm{hr}\right.$ at $\left.1922^{\circ} \mathrm{F}\right)$ for grain enlargement, was below that of pure platinum. The creep rate of normally annealed palladium under stresses of 150 and 250 psi was very high for the first $1200 \mathrm{hr}$ but fell to a low value thereafter. Heating the palladium at $1382^{\circ} \mathrm{F}\left(750^{\circ} \mathrm{C}\right)$ for $1200 \mathrm{hr}$ virtually eliminated the first stage of creep and also lowered the rate in the second stage.

\section{Acknowledgment}

The authors wish to take this opportunity of thanking Baker \& Co., of Newark, N. J., for their cooperation both in lending the platinum metals and in preparing the specimens. The authors are grateful to N. B. Pilling, Director of Research, International Nickel Co., for permission to publish these data, to E. M. Wise for suggestions and to W. T. Coughlin and J. W. Whitney for their assistance.

\title{
Technical Note Deformation Texture of Body-Centered Cubic Metal Wires
}

\author{
by W. R. Hibbard, Jr., A. E. Roswell, and A. E. Schuetz
}

$\mathrm{T}$ HE drawn wire texture of body-centered cubic iron, ${ }^{1}$ tungsten, ${ }^{2}$ and molybdenum ${ }^{3}$ has been determined to be a [110] direction parallel to the wire axis. The purpose of this study is to extend the available information on body-centered cubic wire textures to other metals and alloys.

Wires were produced using hand wire rolls and dies as given in Table I. In addition, attempts were unsuccessful to draw wires from chromium, vanadium (Vanadium Corp. of America), and tungsten (Cleveland Tungsten Inc.). Although it is known that wires can be made from these materials, suitable techniques were not readily adaptable.

Where necessary, wires were polished and etched to form flat ribbons 0.005 to 0.007 in. thick, and transmission $\mathrm{X}$-ray patterns were taken using molybdenum radiation with the specimen tilted 0 degrees from the perpendicular toward the beam to critically cover the wire axis. Analyses were made of (110), (002), and (112) reflection circles.

Table I. Wires Used in Study

\begin{tabular}{|c|c|c|c|}
\hline Metal & Source & $\begin{array}{c}\text { Reduct. } \\
\text { in } \\
\text { Diam, } \\
\text { Pet }\end{array}$ & Remarks \\
\hline $\begin{array}{l}\beta \text { brass } \\
(51.92 \mathrm{pct})\end{array}$ & American Brass Co. & 78.1 & Hot worked at $600^{\circ} \mathrm{C}$ \\
\hline$\beta$ brass & Scovill Mfg. Co. & 71.2 & $\begin{array}{l}\text { Quenched from } 875^{\circ} \mathrm{C} \text {, } \\
\text { Cold formed }\end{array}$ \\
\hline $\begin{array}{l}\text { Iron } \\
\text { Molybdenum }\end{array}$ & $\begin{array}{l}\text { Armco } \\
\text { North American } \\
\text { Phillips }\end{array}$ & $\begin{array}{l}97 \\
93\end{array}$ & $\begin{array}{l}\text { Cold formed } \\
\text { Hot formed starting at } \\
550^{\circ} \mathrm{C} \text {, finished at } \\
110^{\circ} \mathrm{C}\end{array}$ \\
\hline $\begin{array}{l}\text { Niobium } \\
\text { Tantalum } \\
\end{array}$ & $\begin{array}{l}\text { Rem-Cru } \\
\text { Fansteel }\end{array}$ & $\begin{array}{l}95 \\
97\end{array}$ & $\begin{array}{l}\text { Cold formed } \\
\text { Cold formed }\end{array}$ \\
\hline
\end{tabular}

In all cases reflection maxima indicated the texture to be a single [110] deformation fiber, as illustrated by Fig. 1 for molybdenum. In the case of the hot-worked $\beta$ brass, a second texture, [100], was also found, but this is believed to be the result of recrystallization since it has been reported for recrystallized molybdenum wires ${ }^{4}$ and it was not present in the cold-drawn $\beta$ brass. The difference

W. R. HIBBARD, JR., Member AIME, formerly Associate Professor, Department of Metallurgy, Yale University, is now with General Electric Co., Schenectady. A. E. ROSWELL and A. E. SCHUETZ are with the Department of Metallurgy, Yale University, New Haven, Conn.

TN 86E. Manuscript, May 21, 1951.

This note is based on research oided by a Grant-in-Aid from the Research Fund of the Society of the Sigma Xi and the Scientific Research Society of America.

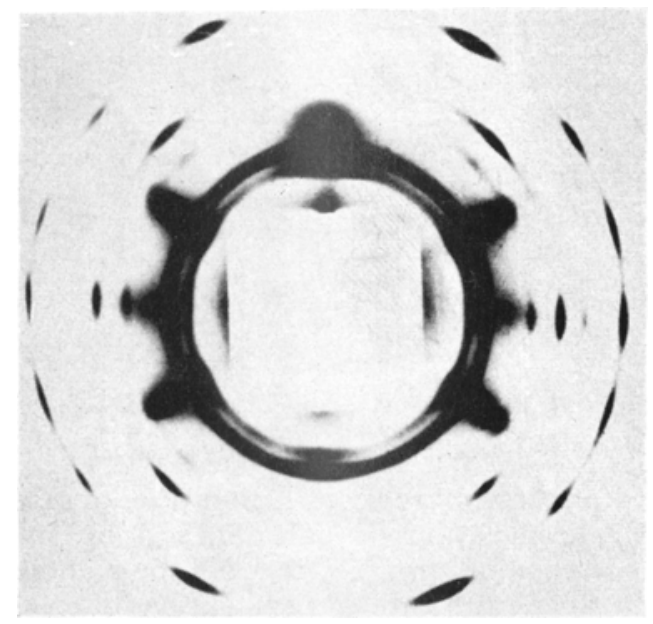

Fig. 1-Molybdenum wire drawn 93 pct reduction in diam. Wire axis verticle tilted $10^{\circ}$ from perpendicular toward the beam. (110) ring shows maxima at $0^{\circ}, 60^{\circ}$, and $90^{\circ}$ from wire and $90^{\circ}$ indicating a single $[110]$ texture.

in drawability between the 51.92 pct $\mathrm{Cu} \beta$ brass and the 62.5 pct $\mathrm{Cu} \beta$ brass (containing some grain boundary $\alpha$ due to incomplete quenching) is quite striking, since the latter could be cold worked readily while the former had to be hot worked to avoid cracking.

\section{Summary}

The deformation texture of drawn body-centered cubic wires of $\beta$ brass, iron, molybdenum, niobium, and tantalum is essentially a single [110] fiber as predicted by theory. ${ }^{5}$

\section{Acknowledgment}

The authors wish to thank the suppliers of the metals listed in the text, and the Grant-in-Aid from the Research Fund of the Society of the Sigma Xi and Scientific Research Society of America which made possible the purchase of X-ray equipment.

\section{References}

${ }^{1}$ C. S. Barrett and L. H. Levenson: Trans. AIME (1939) 135, p. 327.

${ }^{2}$ M. Ettisch, M. Polyani, and K. Weissenberg: Ztsch. Physik (1921) \%, p. 181

${ }^{3}$ Z. Jeffries: Trans. AIME (1924) 70, p. 303.

${ }^{4}$ T. Fujiwara: Proc. World Eng. Cong., Tokyo, 1929 (1931) 36, pt. 4, p. 171

${ }^{5}$ W. R. Hibbard, Jr. and M. K. Yen: Trans. AIME (1948) 175, p. 126; Metals Technology (February 1948). 